\title{
KESADARAN MASYARAKAT TERHADAP PENYAKIT MENTAL
}

\author{
Oleh: \\ Berry Choresyo, Soni Akhmad Nulhaqim, \& Hery Wibowo
}

\begin{abstract}
Abstrak
Tulisan ini bertujuan untuk membahas tentang keberadaan penykit mental yang muncul di masyarakat namun kurang disadari oleh masyarakat itu sendiri sehingga seringkali menimbulkan perlakuan maupun anggapan yang salah terhadap penderita kelainan mental baik anak-anak maupun orang dewasa. Hal tersebut terjadi karena kurangnya pengetahuan masyarakat untuk mengidentifikasi berbagai kelainan mental dan kurangnya kesadaran untuk menghubungi pihak ahli yang mampu menangani penyakit mental tersebut. Sosialisasi terkait penyakit mental sangat diperlukan karena fenomena kelainan mental seperti autism, down syndrome maupun penyakit mental lainnya yang juga bisa terjadi pada orang dewasa seperti Skizofrenia, bipolar atau depresi berat, sudah ada sejak dulu dan fenomenanya masih sering ditemukan namun pemahaman akan hal ini masih kurang di masyarakat, terutama masyarakat daerah pedalaman atau terpencil.
\end{abstract}

\section{Pendahuluan}

Kesehatan merupakan keadaan sejahtera dari badan, jiwa dan sosial. Kondisi ini adalah sesuatu yang sangat dibutuhkan oleh setiap manusia untuk menjalankan kehidupannya dengan baik.

Kesehatan mental merupakan terwujudnya keharmonisan antara fungsi-fungsi jiwa, serta kesanggupan untuk menghadapi problem-problem biasa yang terjadi dan merasakan secara positif kebahagiaan dan kemampuan dirinya. (Zakiyah Darojah, 1975). Kesehatan mental atau dapat juga disebut Kesehatan jiwa adalah keadaan jiwa yang sehat menurut ilmu kedokteran sebagai unsur kesehatan, yang dalam penjelasannya disebutkan bahwa kesehatan jiwa adalah suatu kondisi yang memungkinkan perkembangan fisik, intelektual dan emosional yang optimal dari seseorang dan perkembangan itu berjalan selaras dengan keadaan orang lain. Makna kesehatan jiwa mempunyai sifat-sifat yang harmonis (serasi) dan memperhatikan semua segi-segi dalam kehidupan manusia dan dalam hubungannya dengan manusia lain.

Gangguan jiwa atau penyakit mental adalah pola psikologis atau perilaku yang pada umumnya terkait dengan stres atau kelainan mental yang tidak dianggap sebagai bagian dari perkembangan normal manusia. Gangguan tersebut didefinisikan sebagai kombinasi afektif, perilaku, komponen kognitif atau persepsi, yang berhubungan dengan fungsi tertentu pada daerah otak atau sistem syaraf yang menjalankan fungsi sosial manusia, kerja dan fisik individu.

Kurangnya kesadaran dan pengetahuan masyarakat tentang penyakit atau kelainan mental, seringkali menimbulkan perlakuan yang salah terhadap penderita penyakit mental. Seperti contohnya terdapat fenomena dimana keluarga di daerah pelosok Indonesia lebih memilih memasung anggota keluarganya yang mengidap penyakit mental seperti Skizofrenia ketimbang membawanya ke rumah sakit. Belum lagi penderita penyakit mental yang diolok-olok dan dijauhi lingkungannya karna dianggap menyusahkan. Ada terdapat banyak jenis penyakit mental diluar down syndrome dan autisme yang sulit terdeteksi melalui penampilan luar dan bukan merupakan bawaan dari lahir seperti contohnya schizophrenia, bipolar disorder, manic, depresi, paranoid dan lain-lain. Di masyarakat banyak beredar kepercayaan atau mitos yang salah mengenai penyakit mental, ada yang percaya 
bahwa penyakit mental disebabkan oleh gangguan roh jahat, ada yang menuduh bahwa itu akibat guna-guna, karena kutukan atau hukuman atas dosanya. Kepercayaan yang salah ini hanya akan merugikan penderita dan keluarganya karena pengidap penyakit jiwa tidak mendapat pengobatan secara cepat dan tepat.

Kurangnya pengetahuan masyarakat Indonesia tentang keberadaan berbagai penyakit mental, cara mengidentifiksinya dan bagaimana menanganinya, seringkali menjadi pemicu terjadinya perlakuan yang salah dari masyarakat terhadap penderita. Kurangnya pengetauhan akan gejala-gejala penyakit mental juga membuat orang yang sebenarnya mengalami gejala penyakit mental menjadi tidak sadar dan enggan berkonsultasi dengan spesialis kejiwaan untuk memeriksa keadaan jiwanya.

Hasil Riset Kesehatan Dasar (Riskesda) Indonesia 2007 menunjukkan bahwa penderita gangguan jiwa berat (psikosis) di Indonesia adalah 0.46 persen atau sejuta orang. Dari total populasi risiko 1,093,150 hanya 3.5 persen atau 38,260 yang baru terlayani di rumah sakit jiwa, rumah sakit umum, atau pusat kesehatan masyarakat dengan fasilitas memadai. Penyakit mental tidak hanya terjadi pada orang dewasa yang mengalami tekanan pada hidupnya, banyak juga penyakit mental yang tidak terlihat secara fisik terjadi pada anak-anak. Seperti contohnya ADHD (Attention Deficit Hyperactivity Disorder) yang tidak terlihat secara fisik namun dapat diidentifikasi melalui tingkah laku anak yang seperti tidak bisa diam, sulit mendengarkan perintah, tidak sabaran dan tidak bisa fokus. Jika orang tua tidak menyadari hal ini dan tidak memberikan treatment yang tepat, anak yang mengidap penyakit tersbut akan tumbuh dewasa dengan terus membawa gejala tersebut dan sulit untuk bersosialisasi dengan orang lain. Maka dari itu, penting bagi masyarakat Indonesia baik di daerah perkotaan sampai pedesaan untuk mengetahui dan mengenal gejala-gejala penyakit mental dan mengerti apa yang harus dilakukan untuk menangani hal tersebut dan juga mengerti bagaimana perlakuan kita seharusnya ketika menemui penderita penyakit mental di sekitar kita.

\section{Pembahasan}

Definisi dan Penyebab

Penyakit mental adalah penyakit yang melibatkan gangguan pada fungsi otak yang boleh menyebabkan perubahan kepada proses pemikiran, perasaan dan tingkah-laku seseorang yang mengakibatkan gangguan untuk menjalani aktivitas seharian dengan baik. Contoh-contoh yang termasuk kedalam penyakit mental atau yang biasa disebut juga kelainan mental antara lain: Depresi, Anxiety Disorder (Rasa Takut), Skizofrenia, Attention Deficit Hyperactive Disorder (ADHD), Eating disorder sampai kepada tindakan adiksi yang atau kecanduan terhadap sesuatu yang tidak wajar seperti obat-obatan atau bahan kimia tertentu. Banyak orang yang mengalami kejanggalankejanggalan yang terjadi pada mentalnya seperti misalnya merasa stress, depresi takut, maupun gelisah, kondisi tersebut dapat juga dikatakan sebagai gejala awal dari gangguan mental, namun baru dapat dikatakan sebagai sebuah gangguan mental apabila perasaan-perasaan tersebut sudah melewati batas kewajaran sehingga mengganggu keberfungsian sosial atau dapat juga berpengaruh kepada menurunnya kondisi kesehatan secara jasmani. Gangguan mental dapat mengganggu kehidupan sehari-hari dan menimbulkan banyak masalah dalam keberfungsian sosial seperti tidak dapat bekerja sama dengan orang lain atau menjalin hubungan dengan orang lain. Gejala-gejala dan penyakit mental tersebut dapat disembuhkan melalui konseling dan terapi oleh ahli kejiwaan atau psikiater.

Penyebab terjadinya penyakit mental belum ditemukan secara jelas dan sangat bervariasi. Namun dalam penelusurannya, penyebab utamanya kemungkinan di badan (somatogenik), dilingkungan sosial (sosiogenik) ataupun pada psikologis (psikogenik). Biasanya tidak terdapat penyebab tunggal, akan tetapi beberapa penyebab sekaligus dari berbagai unsur itu yang saling mempengaruhi atau kebetulan terjadi bersamaan, lalu timbullah gangguan badan ataupun jiwa. Umpamanya seorang dengan depresi, karena kurang makan dan tidur daya tahan badaniah seorang berkurang sehingga mengalami keradangan tenggorokan atau seorang dengan mania mendapat kecelakaan. 
Sebaliknya seorang dengan penyakit badaniah umpamanya keradangan yang melemahkan, maka daya tahan psikologiknya pun menurun sehingga ia mungkin mengalami depresi. Sudah lama diketahui juga, bahwa penyakit pada otak sering mengakibatkan gangguan jiwa. Contoh lain ialah seorang anak yang mengalami gangguan otak (karena kelahiran, keradangan dan sebagainya) kemudian menadi hiperkinetik dan sukar diasuh. Ia mempengaruhi lingkungannya, terutama orang tua dan anggota lain serumah. Mereka ini bereaksi terhadapnya dan mereka saling mempengaruhi.

Sumber penyebab gangguan jiwa dipengaruhi oleh faktor-faktor pada ketiga unsur itu yang terus menerus saling mempengaruhi, yaitu:

1. Faktor keturunan

Pada mongoloisme atau sindroma Down (suatu macam retardasi mental dengan mata sipit, muka datar, telinga kecil, jari-jari pendek dan lain-lain) terdapat trisoma (yaitu tiga buah, bukan dua) pada pasangan Kromosoma No. 21.

Sindroma Turner (dengan ciri-ciri khas : tubuh pendek, leher melebar, infantilisme sexual) ternyata berhubungan dengan jumlah kromosima sex yang abnormal. Gangguan yang berhubungan dengan kromosoma sex dikatakan "terikat pada sex" ("sex linked"), artinya bahwa efek genetik itu hanya terdapat pada kromosoma sex. Kaum wanita ternyata lebih kurang peka terhadap gangguan yang terikat pada sex, karena mereka mempunyai dua kromosoma $\mathrm{X}$ : bila satu tidak baik, maka yang lain biasanya akan melakukan pekerjaannya. Akan tetapi seorang pria hanya mempunyai satu kromosoma $\mathrm{X}$ dan satu kromosoma $\mathrm{Y}$, dan bila salah satu tidak baik, maka terganggulah ia. Masih dipermasalahkan, betulkan pria dengan XYY lebih cenderung melakukan perbuatan kriminal yang kejam?

\section{Faktor Konstitusi}

Konstitusi pada umumnya menunjukkan kepada keadaan biologik seluruhnya, termasuk baik yang diturunkan maupun yang didapati kemudian; umpamanya bentuk badan (perawakan), sex, temperamen, fungsi endoktrin daurat syaraf jenis darah Jelas bahwa hal-hal ini mempengaruhi perilaku individu secara baik ataupun tidak baik, umpamanya bentuk badan yang atletik atau yang kurus, tinggi badan yang terlalu tinggi ataupun terlalu pendek, paras muka yang cantrik ataupun jelek, sex wanita atau pria, fungsi hormonal yang seimbang atau yang berlebihan salah satu hormon, urat syaraf yang cepat reaksinya atau yang lambat sekali, dan seterusnya. Semua ini turut mempengaruhi hidup seseorang.

\section{Cacat Kongenital}

Cacat kongenital atau sejak lahir dapat mempengaruhi perkembangan jiwa anak, terlebih yang berat, seperti retardasi mental yang brat. Akan tetapi pada umumnya pengaruh cacat ini pada timbulnya gangguan jiwa terutama tergantung pada individu itu, bagaimana ia menilai dan menyesuaikan diri terhadap keadaan hidupnya yang cacat atau berubah itu.

Orang tua dapat mempersukar penyesuaian ini dengan perlindungan yang berlebihan (proteksi berlebihan). Penolakan atau tuntutan yang sudah di luar kemampuan anak. Singkatnya : kromosoma dan "genes" yang defektif serta banyak faktor lingkungan sebelum, sewaktu dan sesudah lahir dapat mengakibatkan gangguan badaniah. Cacat badaniah biasanya dapat dilihat dengan jelas,tetapi gangguan sistim biokimiawi lebih halus dan sukar ditentukan. Gangguan badaniah dapat mengganggu fungsi biologik atau psikologik secara langsung atau dapat mempengaruhi daya tahan terahdap stres.

4. Perkembangan Psikologik yang salah, Perkembangan psikologik yang salah, seperti:

a. Ketidak matangan atau fixasi, yaitu inidvidual gagal berkembang lebih lanjut ke fase berikutnya;

b. "Tempat-tempat lemah" yang ditinggalkan oleh pengalaman yang traumatik sebagai kepekaan terhadap jenis stres tertentu, atau 
c. disorsi, yaitu bila inidvidu mengembangkan sikap atau pola reaksi yang tidak sesuai atau gagal mencapai integrasi kepribadian yang normal. Kita akan membicarakan beberapa faktor dalam perkembangan psikologik yang tidak sehat

\section{Deprivasi dini}

Deprivasi maternal atau kehilangan asuhan ibu di rumah sendiri, terpisah dengan ibu atau di asrama, dapat menimbulkan perkembangan yang abnormal. Deprivasi rangsangan umum dari lingkungan, bila sangat berat, ternyata berhubungan dengan retardasi mental. Kekurangan protein dalam makanan, terutama dalam jangka waktu lama sebelum anak breumur 4 tahun, dapat mengakibatkan retardasi mental.

Eprivasi atau frustrasi dini dapat menimbulkan "tempat-tempat yang lemah" pada jiwa, dapat mengakibatkan perkembangan yang salah ataupun perkembangan yang berhenti. Untuk perkembangan psikologik rupanya ada "masa-masa gawat". Dalam masa ini rangsangan dan pengalaman belajar yang berhubungan dengannya serta pemuasan berbagai kebutuhan sangat perlu bagi urut-urutan perkembangan intelektual, emosional dan sosial yang normal

\section{Pola keluarga yang petagonik}

Dalam masa kanak-kanak keluarga memegang peranna yang penting dalam pembentukan kepriadian. Hubungan orangtua-anak yang salah atau interaksi yang patogenik dalam keluarga sering merupakan sumber gangguan penyesuaian diri.

Kadang-kadang orangtua berbuat terlalu banyak untuk anak dan tidak memberi kesempatan anak itu berkembang sendiri. Ada kalanya orangtua berbuat terlalu sedikit dan tidak merangsang anak itu atau tidak memberi bimbingan dan anjuran yang dibutuhkannya. Kadang-kadang mereka malahan mengajarkan anak itu pola-pola yang tidak sesuai.

Akan tetapi pengaruh cara asuhan anak tergantung pada keadaan sosial secara keseluruhan dimana hal itu dilakukan. Dan juga, anak-anak bereaksi secara berlainan terhadap cara yang sama dan tidak semua akibat adalah tetapi kerusakan dini sering diperbaiki sebagian oleh pengalaman di kemudian hari. Akan tetapi beberapa jenis hubungan orangtua-anak sering terdapat dalam latar belakang anakanak yang terganggu, umpamanya penolakan, perlindungan berlebihan, manja berlebihan, tuntutan perfeksionistik, standard moral yang kaku dan tidak realistik, disiplin yang salah, persaingan antar saudara yang tidak sehat, contoh orangtua yang salah, ketidak-sesuaikan perkawinan dan rumah tangganya yang berantakan, tuntutan yang bertentangan.

\section{Jenis-Jenis penyakit mental:}

Penyakit mental memiliki jenis atau tipe berbeda yang juga akan berpengaruh terhadap tingkat parahnya penyakit. Beberapa tipe penyakit sosial yang ada antara lain: Anxiety Disorder (Paranoid), Depresi, Skizofrenia, Bipolar Mood Disorder, Personality Disorder, Trauma dan kelainan makan. Penyakit sosial yang paling umum terjadi adalah Paranoid dan depresi.Terkadang ada saatnya manusia berhadapan dengan perasaan tertekan, ketakutan atau kesedihan. Perasaan yang terlalu kuat dari itu akan menimbulkan gejala awal depresi atau Anxiety Disorder dan hal tersebut dapat mengganggu kehidupan sehari-hari dan bisa juga merusak hubungan sosial dengan orang lain dan dalam kondisi yang lebih parah, seseorang dengan gejala depresi dapat berhari-hari tidak mau keluar dari kamar dan tidak mau berhubungan dengan dunia luar serta tidak peduli akan kesehatan badannya. Sesorang yang mengalami Paranoid, dalam kondisi yang parah, bisa saja tidak mau meninggalkan kamar atau rumah karena merasa terancam akan sesuatu yang sebenarnya tidak mengancam dirinya. Penderita Paranoid, biasanya juga memiliki ritual tertentu yang terbilang janggal untuk membuang rasa takut dari dalam dirinya. 
Jenis penyakit mental lain yang lebih sedikit ditemukan adalah jenis penyakit mental yang berhubungan dengan kegilaan (psychosis) contoh dari jenis ini adalah Skizofrenia dan Bipolar mood disorder.

\section{$\underline{\text { Skizofrenia }}$}

Skizofrenia biasanya terjadi pada usia muda antara akhir usia remaja hingga 20an akhir, penyakit ini merupakan gangguan pada kemampuan kognitif, emosi dan tingkah laku yang masih belum ditemukan pasti penyabab terjadinya. Tanda-tanda gejala orang yang menderita skizofrenia adalah sebagai berikut:

1. Delusi: Penderita skizofrenia tidak mampu membedakan realita dan khayalan. Penderita lebih sering mempercayai bahwa apa yang ada di dalam khayalannya adalah kenyataan dan tidak menyadari keadaan realita yang sebenarnya

2. Halusinasi: Mendengar atau melihat sesuatu yang tidak nyata.

3. Berbicara Tidak Jelas: Tidak mampu berbicara dengan baik, seperti memberikan jawaban yang tidak sesuai dengan pertanyaan yang ditanyakan dalam percakapan sehari-hari.

4. Gejala Negatif: Yang dimaksud disini adalah tidak berjalannya fungsi emosi manusia. Seperti misalnya berbicara datar tanpa nada atau ekspresi wajah, tidak melihat ke lawan bicara ketika sedang berbicara, tidak memiliki semangat atau minat terhadap kegiatan sehari-hari dan tidak memiliki niat dalam melakukan interaksi sosial dengan orang lain.

\section{Bipolar Disorder}

Bipolar Disorder adalah kondisi dimana ada ketidakjelasan antara perasaan Manic (Euforia) dan Depresif. Penderita bipolar dapat seketika merasa senang luar biasa dan kemudian secara tiba-tiba merasa depresif, bertolak belakang dari apa yang dirasa sebelumnya, tanpa ada sebab yang jelas. Bipolar disorder merusak sistem kerja emosi seseorang. Hal ini dapat merusak keberfungsian sosial dan hubungan sosialnya di masyarakat sebagaimana penderita tidak memiliki keadaan emosi yang tidak jelas dan bisa saja tiba-tiba melakukan sesuatu yang merugikan orang lain. Bipolar disorder memiliki dua fase yaitu Manic dan Depressive. Gejala yang muncul ketika penderita ada dalam fase manic antara lain: Euforia, Rasa percaya diri yang tinggi, Agresif, berdelusi, kehilangan rasa takut dan berani mengambil resiko dalam batas yang tidak normal. Sementara dalam fase depresif: Penderita mengalami kesedihan, putus asa, rasa takut, menyesal, kelelahan, rasa sakit tanpa ada sebab dan memiliki keinginan untuk bunuh diri. Penderita bipolar seringkali mengalami kedua fase tersebut secara berubah-ubah tanpa ada sebab yang jelas dan gejala ini tidak hanya terjadi pada orang dewasa atau remaja, tapi juga bisa terjadi pada anak-anak dan inilah yang seringkali tidak disadari oleh para orang tua sehingga anak yang menderita bipolar tidak mendapat penanganan yang tepat.

\section{Attention Deficit Hyperactivity Disorder (ADHD)}

Ada jenis penyakit mental terjadi yang pada anak, diluar down syndrome atau autisme yang secara fisik sudah dapat teridentifikasi yaitu Attention Deficit Hyperactivity Disorder (ADHD) Penyakit mental ini biasanya hanya terjadi pada anak-anak, namun apabila penyakit mental ini tidak mendapat penanganan hingga si anak tumbuh dewasa, sifat-sifat buruk dari kelainan ini akan terus terbawa dan menjadikan anak tersebut menjadi sulit bersosialisasi dan berhubungan dengan orang lain ketika sudah bertumbuh dewas. Anak yang menderita ADHD biasanya sulit fokus dan menerima perintah. Tidak sabaran, cepat bosan atau marah serta bertindak impulsif dalam batasan yang tidak normal. Perasaan kurang percaya diri, selalu cemas dan selalu merasa kurang adalah hal yang sering terjadi pada penderita ADD dewasa ang sudah membawa penyakit tersebut sejak kecil. Walaupun banyak penderita sebenarnya cerdas, kreatif, dan energik, mereka sering merasa harus berupaya lebih keras dari orang lain untuk mendapat kedudukan yang sama. 
Salah satu karakteristik utama adalah perasaan berlebihan bahwa mereka tidak berhasil. Mereka mencari pertolongan karena tidak dapat bekerja dengan teratur. Mereka menjadi kecewa dan frustrasi. Sekalipun sudah berusaha, mereka tidak pernah kelihatan berhasil menuntaskan pekerjaan yang mereka lakukan dan selalu tidak yakin dengan potensi mereka sesungguhnya.

Penderita ADD juga gampang depresi, cemas, dan kelelahan. Karena mereka selalu bekerja, mereka cenderung tidak menjaga diri dengan baik, sering mengandalkan makanan cepat saji dan mengorbankan waktu tidur untuk menuntaskan pekerjaannya. Karena kondisi ini menyebabkan mereka sering mengalami stres dan kecemasan. Mereka akan mencari hiburan dan minum minuman keras atau mengonsumsi obat-obatan. Mereka juga jadi gemar mengambil risiko dan gampang terlibat dalam perjudian, kekerasan, atau pergaulan bebas. Mereka suka hidup di 'jalur cepat' dan harus merasa terstimulasi setiap saat. Maka akhirnya mereka bertindak berlebihan, lah yang perlu disadari oleh orang tua dalam memperhatikan anaknya yang masih kecil. Kesadaran akan penyakit ini sangat diperlukan untuk mencegah kerusakan yang lebih lagi dalam keberfungsian sosial di kemudian hari.

\section{Kesadaran Masyarakat}

Sudah seharusnya masyarakat Indonesia memiliki kesadaran yang cukup tinggi terhadap fenomena penyakit mental karena fenomena sudah lama ada dan hingga hari ini masih banyak orang-orang yang secara tidak sadar menderita penyakit mental namun tidak ada orang disekitarnya juga yang cukup memahami kondisi kejiwaannya dan merujuknya ke pihak yang ahli dalam menangani penyakit mental. Citra yang terbentuk di dalam sebagian besar masyarakat Indonesia terhadap penderita penyakit mental atau lebih sering dikenal dalam percakapan sehari-hari dengan sebutan "sakit jiwa" atau "gila", masih merupakan sesuatu yang memalukan. Banyak keluarga yang merasa malu untuk membawa anggota keluarganya ke rumah sakit jiwa karena anggapan buruk terhadap penyakit mental yang telah terbentuk di masyarakat Indonesia dan akhirnya penderita penyakit mental tidak mendapatkan penanganan yang semestinya dan kondisi bisa saja menjadi lebih parah. Tidak sedikit juga, keluarga yang menolak atau mengusi anggota keluarganya yang bertingkah laku aneh karena penyakit mental diderita. Hal tersebut biasanya terjadi karena kurangnya pengetahuan tentang gejalagejala penyakit mental yang mungkin terjadi pada manusia sehingga tidak ada pengertian atas tindakan tidak wajar yang dilakukan penderita dan juga tidak ada upaya pengobatan atau dukungan dari anggota keluarga dan masyarakat sekitarnya untuk membantu kesembuhannya. Persepsi yang juga berkembang dalam masyarakat adalah bahwa gangguan jiwa merupakan penyakit yang terjadi karena hal-hal mistis sehingga kadang masyarakat melakukan tindakan penanganan yang salah terhadap penderita penyakit mental.

Ketua Asosiasi Rumah Sakit Jiwa dan Ketergantungan Obat Indonesia (ARSAWAKOI), dr Bambang Eko Suryananto, SpKJ, menjelaskan, Gangguan jiwa yang terjadi pada seseorang, menurut Bambang, disebabkan oleh interaksi manusia sebagai makhluk bio-psiko-sosio-spiritual. Secara biologis, penyakit mental seperti contohnya skizofrenia disebabkan karena peningkatan neurotransmitter dopamin di otak, sehingga dapat timbul gejala-gejala perilaku, gangguan persepsi (mendengar suara meskipun tidak ada sumber suara), gangguan isi pikir yang berupa keyakinankeyakinan tertentu yang tidak wajar, dan lain-lain.

\section{Kesimpulan}

Penyakit mental tetaplah sebuah penyakit yang mengganggu keberfungsian manusia namun hanya saja tidak secara fisik, melainkan mental, namun bukan berarti penyakit mental tidak dapat disembuhkan. Ketua Asosiasi Rumah Sakit Jiwa dan Ketergantungan Obat Indonesia (ARSAWAKOI), dr Bambang Eko Suryananto, SpKJ, menjelaskan, sudah banyak kisah sukses seorang penderita penyakit mental berat seperti skizofrenia atau bipolar disorder dapat disembuhkan dan dapat kembali bertingkah normal. Jika pasien segera dibawa berobat pada tahap awal menderita penyakit, penurunan fungsi peran dapat diminimalkan. Namun, masalahnya adalah stigma 
masyarakat tentang gangguan jiwa seringkali membuat pasien skizofrenia terlambat dibawa ke petugas kesehatan. Pentingnya dukungan keluarga juga dapat menjadi faktor keberhasilan pasien kelainan mental untuk sembuh. Karena itu, diperlukan adanya peningkatan pengetahuan dan wawasan seputar penyakit mental di masyarakat luas supaya tidak lagi beredar anggapan yang salah dan memunculkan kesadaran untuk lebih peduli dan memhami penanganan penderita penyakit mental.

\section{Daftar Rujukan}

Kaplan, Tony. 2009. Children and Adolescent with Mental Health Problems. The Royal College of Psychiatrists: London.

Williams, Lippincott. 2000. Kaplan \& Sadock's Comprehensive Textbook of Psychiatry 7th edition. Wilkins Publisher: Baltimore, United States

Schneiders, Alexander. 1955. Personal Adjusment and Mental Health. Rinehart \& Company: United States

Semrud-Clikeman, Margaret. 2007. Social Competence in Children. Springer Science+Business Media, LCC: USA.

Hallowell, Edward. 1995. Driven to Distraction: Recognizing and Coping with Attention Deficit Disorder from Childhood Through Adulthood. Touchstone: New York, United States.

www.mayoclinic.org. disease and condition of mental illness. Diunduh pada 9 desember 2014 pukul 19.35 WIB

www.academia.edu. Jurnal. Buku Ajar Kesehatan Mental. Diunduh pada 14 desember 2014 pukul 14.52 WIB

www.mayoclinic.org. Schizophrenia Symptoms. Diunduh pada 14 desember 2014 pukul 16.57 WIB www.mayoclinic.org. Bipolar Disorder Symptoms. Diunduh pada 14 desember 2014 pukul 19.12 WIB

www.academia.edu. Nur, Margo. Jurnal. FAKTOR PENYEBAB DAN PROSES TERJADINYA GANGGUAN MENTAL. Diunduh pada 13 desember 15.47 WIB

http://psikologi.or.id/psikologi-umum-pengantar/pengertian-definisi-gangguan-jiwa diunduh pada 9 desember pukul 17.44 WIB

http://health.kompas.com. Gangguan Jiwa Masih Diabaikan. Diunduh Pada Tanggal 13 Desember 2014 Pukul 22.31 WIB

http://www.republika.co.id/berita/nasional/umum/13/10/15/mupu4v-atasi-skizofrenia-perluperhatian-bersama. Diunduh pada 15 desember pukul 11.04 WIB

www.jurnal.upi.edu. Purwanti, Isti. Pengantar Kesehatan Mental. Diunduh pada 9 desember 2014 pukul 18.46 WIB 